\title{
Review on Multi-Pass Friction Stir Processing of Aluminium Alloys
}

\author{
Oritonda Muribwathoho', Sipokazi Mabuwa ${ }^{1 *}$ and Velaphi Msomi ${ }^{1}$ \\ 1 Cape Peninsula University of Technology, Mechanical Engineering Department, Bellville, 7535, South \\ Africa; oritondamuribwathoho@gmail.com; msomiv@cput.ac.za \\ * Correspondence: Mabuwas@cput.ac.za; Tel.: 27219538778
}

\begin{abstract}
Aluminium alloys have evolved as suitable materials for automotive and aircraft industries due to their reduced weight, excellent fatigue properties, high-strength to weight ratio, high workability/formability, and corrosion resistance. Recently, the joining of similar and dissimilar metals have achieved huge success in various sectors. The processing of soft metals like aluminium, copper, iron and nickel have been fabricated using friction stir processing. Friction stir processing (FSP) is a microstructural modifying technique that uses the same principles as the friction stir welding technique. In the majority of studies on FSP, the effect of process parameters on the microstructure was characterized after a single pass. However, multiple passes of FSP is another method to further modify the microstructure in aluminium castings. This study is aimed at reviewing the impact of multi-pass friction stir processed joints of aluminium alloys and to identify a knowledge gap. From the literature that is available on multi-pass FSP, it has been observed that the majority of the literature focused on the processing of plates than the joints. There is limited literature reporting on multi-pass friction stir processed joints. This then creates a need to study further on multi-pass friction stir processing on dissimilar aluminium alloys.
\end{abstract}

Keywords: tensile strength; ductility; microstructure

\section{Introduction}

The use of aluminium alloys has increased over the years due to multiple ranges of its applications. This includes automobile body building, aerospace, marine shipbuilding, food packaging and many other structural applications [1-3]. The interest in the use of the aluminium alloys is based on the appealing characteristics like high strength to weight ratio, appearance, higher ductility and ease of fabrication [4-7]. Various aluminium alloys possess different mechanical and thermal properties and these differences are influenced by the alloying elements used in producing each alloy [6-7]. However, it is a well-known fact that material improvements are very essential for better performance of the material as well for increasing the life span of components [8]. There are many material enhancing techniques including friction stir processing.

Friction stir processing (FSP) is an emerging microstructure modifying technique which uses the same principle as friction stir welding to process materials in a variety of ways besides joining them [9-11]. Mishra et al. [11] developed FSP as a generic tool for microstructural refinement, which eliminates the porosities and thereby resulting in enhanced mechanical properties of the material. During FSP, the rotating pin contacts the surface and rapidly friction heats and softens a small column of metal. The tool shoulder and length of entry probe control the penetration depth. When the shoulder contacts the metal surface, its rotation creates additional frictional heat and plasticizes a larger cylindrical metal column around the inserted pin [10-12]. The shoulder provides a forging force containing the upward metal flow caused by the tool pin. The area to be processed and the tool are moved relative to each other, such that the tool traverses with overlapping passes until the entire selected area is completely processed [13]. Figure 1 shows a schematic diagram of the FSP technique. As a result of the heat generation and severe plastic deformation during the FSP process, the uniform distributed, refined. This therefore results in mechanical properties being affected dramatically [ 1314]. 


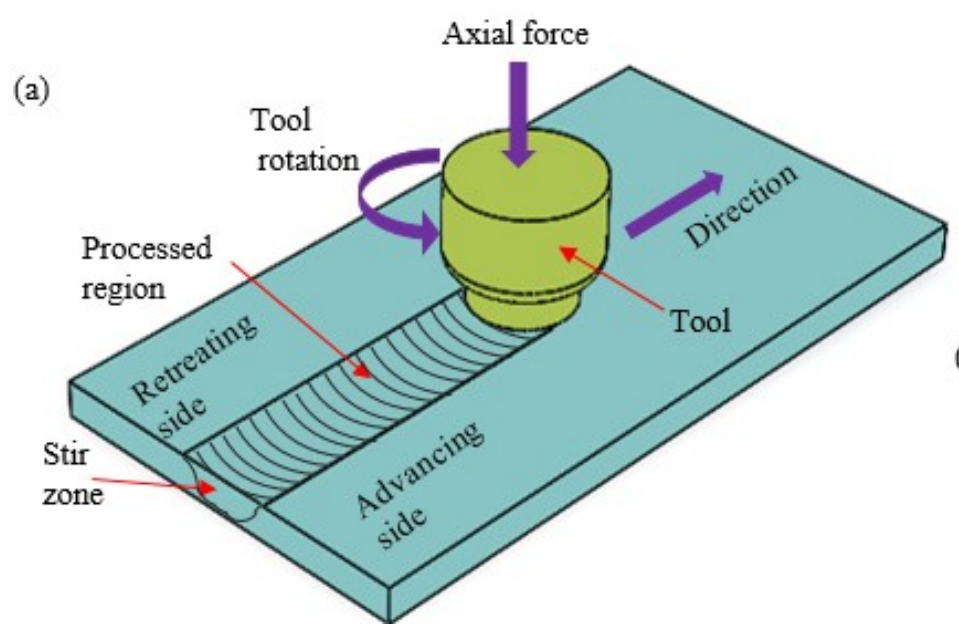

(b)

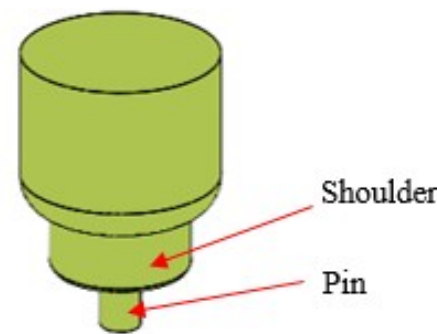

Figure 1. (a) Schematic diagram of FSP technique and (b) FSP Tool.

FSP has been proven to be an effective technique to achieve major microstructural refinement, densification, homogeneity of the processed zone, and elimination of defects from manufacturing processes [15-17]. Processed surfaces have shown an improvement of mechanical properties, such as hardness, tensile strength, fatigue, corrosion and wear resistance [18-19]. In most of the studies on FSP, the effect of process parameters on the microstructure was characterized after a single pass. However, multiple passes of FSP is another method to further modify the microstructure in Al castings. This paper reports on the available literature on the multi-pass FSP of aluminium alloys, to analyse the impact of multi-pass friction stir processed joints of aluminium alloys and to identify a knowledge gap.

\section{Review on available literature}

This section discusses a detailed literature review on multi-pass friction stir processing to tensile, microstructure, hardness and corrosion.

\subsection{Microstructure}

The AA7075 was subjected to multi-pass FSP, to evaluate the microstructural changes as the number of passes increased [20]. A single pass and a total number of four FSP passes were employed. the FSP process was performed under a mixture of methanol, water and dry ice conditions to quench the plate immediately. This was performed to create a structure with ultra-fine grains. The result showed that the microstructural grain size was refined to a sub-micrometre scale of $250 \mathrm{~nm}$. The result proved that ultra-fine grain microstructure can be achieved through the application of multiple FSP passes. A three-pass FSP with 100\% overlap was performed on the AA5083 for the modification of the microstructure and mechanical properties of the alloy [21]. The processing condition included a traverse speed of $360 \mathrm{~mm} / \mathrm{min}$ and a varying tool rotation speed. The single-pass FSP results showed that the stir zone has undergone dynamic recrystallization resulting in equiaxed grains consisting of high angle boundaries (HAGB). The grain size was found to have a linear relationship with the rotational speed. The multi-pass FSP was found to have an insignificant impact on the stir zone microstructural grain size. The high rotational speed stir zone microstructure was reported to be more resistant to abnormal grain growth. Similarly, Brown et al. [22] also reported that the multipass (five-pass) unnoticeable impact in the stir zone microstructure.

El-Rayes and El-Danaf [23] subjected the AA6082-T651 alloy with a $6 \mathrm{~mm}$ thickness to a threepass FSP with $100 \%$ overlap. It was discovered that the stir zone grain size increased with an increase in the number of FSP passes resulting in fraction high angle boundaries. Additionally, more heat was accumulated as the number of FSP passes increased leading to a decrease in the stir zone tensile strength. The high angle boundaries as affirmed by Johannes et al. [24] and Mishra et al. [6] are considered very important for the enhancement of mechanical properties. The impact of the multi- 
pass FSP on the cast aluminium alloy Al-Si-9Mg was investigated [25]. The microstructural results showed that the multi-pass led to a decrease in the grain size while the homogeneity of the microstructure increased. Uniform distribution of second phase particles was found on the microstructure of the processed material compared to those of the cast condition. The processed zone exhibited a decrease in porosity.

A multi-pass FSP was applied on the AA2024 also known as Al-Cu-Mg to investigate the microstructure and crystallographic texture evolution in comparison to a single pass FSP [26]. The stir zone microstructure results revealed features confirming the existence of particle stimulated nucleation caused by the dynamic recrystallization. Moreover, the stir zone was found to have larger grains as a result of geometrical coalescence. All the FSP passes exhibited a stable stir zone microstructure and texture showing the likelihood production of the bulk volume of fine-grained materials using FSP. Akinlabi et al. [27] discovered that the single-pass FSP had a non-homogeneous processed zone resulting in abnormal grain growth, while the multi-pass FSP on the fifth pass revealed a completely homogenous processed zone due to accumulative plastic strain. This, therefore, confirmed that the homogeneity of the processed region is significantly affected by the number of FSP passes.

Various studies where multi-pass FSP was employed to obtain ultra-fine grains were carried through [28-37]. The studies were conducted based on the Hall-Petch method approach. The FSP was conducted using overlapping passes and reduced tool rotational speed. This was done to prove that controlling process parameters can result in grain refinement. Table 1 shows a sample of the processing parameters of the multi-pass FSP discussed in this section.

Table 1. Multi-pass FSP processing parameters - microstructure.

\begin{tabular}{|c|c|c|c|c|c|}
\hline \multirow{2}{*}{$\begin{array}{l}\text { Aluminium } \\
\text { alloy }\end{array}$} & \multicolumn{3}{|c|}{ Parameters } & \multirow{2}{*}{$\begin{array}{l}\text { No. of } \\
\text { passes }\end{array}$} & \multirow[t]{2}{*}{ Reference } \\
\hline & $\begin{array}{l}\text { Tool rotational } \\
\text { speed }(\mathrm{rpm})\end{array}$ & $\begin{array}{l}\text { Traverse } \\
(\mathrm{mm} / \mathrm{min})\end{array}$ & $\begin{array}{l}\text { Material } \\
\text { thickness (mm) }\end{array}$ & & \\
\hline AA7075 & 1000 & 120 & - & 4 & [20] \\
\hline AA5083 & vaying & 360 & 3.5 & 3 & [21] \\
\hline AA7050 & 540 & 406.2 & 6.4 & 5 & [22] \\
\hline AA6082-T651 & 850 & varying & 6 & 3 & [23] \\
\hline AA2024 & 350 & 95 & 6 & 4 & [26] \\
\hline AA6061-T6 & 1600 & 40 & 6 & 5 & [27] \\
\hline A356 & 800 & 120 & 8 & 3 & [30] \\
\hline Al-7Fe-5Ni & vaying & 25 & - & 4 & [31] \\
\hline
\end{tabular}

\subsection{Tensile Properties}

It is undeniable that FSP results in fully equiaxed and recrystallized grains and eliminates casting defects, but in some literature, it was reported that after FSP the mechanical properties deteriorated. This is said to be caused by the material softening in the friction stir processed region. Additionally, in the case of hardness, the decrease is a result of the dissolution of precipitates experienced during FSP [38]. The multiple pass FSP was proven to enhance the mechanical properties, this includes hardness, tensile strength and ductility [27]. This improvement was attributed to the homogeneous processed region of the multi-pass FSP.

The impact of the overlap multi-pass FSP of the die-cast Al-Si-3Cu aluminium alloy was investigated by Baruch et al [39]. The results revealed the tensile strength increased from 121 to 273 MPa. The increase was substantiated to be caused by the refinement in the microstructural grains as the number of passes increased. Simultaneously, an increase from 1.8 to $10 \%$ in fracture strain was reported. The change in the size, shape, morphology and distribution of eutectic silicon particles and elimination of the porosities are the main reasons for the increases in tensile strength and ductility due to friction stir processing. Multi-pass FSP was applied on the AA7075 alloy to produce a superplastic fine-grained microstructure [40]. A single pass and a four-pass FSP was applied on the 
AA7075 plate under similar conditions. The multi-pass FSP exhibited larger areas of superplasticity at different strain rates. However, the single-pass FSP had larger elongation. Additionally, the primary mechanism for superplastic deformation of the multi-pass FSP was owed to the grain boundary sliding. While the study by Ma et al. [41] found the two-pass FSP to consist of a higher elongation.

Meenia et al. [42] investigated the effect of multi-pass FSP on the microstructure and mechanical properties of the hypeutectic Al-Si alloy. A total of three passes was applied. The three pass FSP had the most refined grain structure and showed maximum ductility compared to the single-pass FSP. The tensile strength also followed the same pattern. Additionally, the application of the multi-pass FSP on the same alloy was proven to result in an increase in elongation and the tensile strength [43]. Rao et al. [44] examined the impact of a two-pass with $100 \%$ overlapping FSP on the hypereutectic Al-30Si alloy. The tensile strengths of the multi-pass friction stir processed specimens are much higher than that of the cast aluminium alloy. Similar results where the application of multi-pass resulted in a higher tensile strength than that of the base material were obtained by Pradeep et al. [45] and Nakata et al. [46].

El-Rayes et al. [23] proved that the tensile strength decreases with an increase in the number of FSP passes of the 6082 alloy. The increase in the traverse speed was reported to results in an increase in mean hardness and stir zone tensile strength. Ramesh et al. [47] subjected the AA5086 -O plates to a twelve-pass FSP with a 50\% overlap using two FSP methods. The employed methods were the intermittent multi-pass (IMP) FSP and continuous multi-pass (CMP) FSP. The influence of these two methods on the mechanical properties of the AA5086 alloy was studied comparatively. The results revealed that better mechanical properties were found on the specimens subjected to IMP FSP. There are various studies where the tensile and elongation increased due to multi-pass FSP [48-55]. Table 2 present a sample of the process parameters of the discussed multi-pass FSP in this section.

Table 2. Multi-pass FSP processing parameters - tensile properties.

\begin{tabular}{|c|c|c|c|c|c|}
\hline \multirow{2}{*}{$\begin{array}{l}\text { Aluminium } \\
\text { alloy }\end{array}$} & \multicolumn{3}{|c|}{ Parameters } & \multirow{2}{*}{$\begin{array}{l}\text { No. of } \\
\text { passes }\end{array}$} & \multirow{2}{*}{ Reference } \\
\hline & $\begin{array}{l}\text { Tool rotational } \\
\text { speed (rpm) }\end{array}$ & $\begin{array}{l}\text { Traverse speed } \\
(\mathrm{mm} / \mathrm{min})\end{array}$ & $\begin{array}{l}\text { Material } \\
\text { thickness (mm) }\end{array}$ & & \\
\hline AS7U3G & 600 & 12 & 10 & 3 & [43] \\
\hline LM25 & 800 & 120 & 8 & 3 & [46] \\
\hline Al-30Si & 1000 & 16 & 12 & 2 & [48] \\
\hline AA5086 & 720,1025 & 155,50 & 6 & 28 & [49] \\
\hline $\mathrm{ADC12}$ & 1250 & 500 & 4 & 14 & [50] \\
\hline AA5086 & 1025 & varying & 6 & 12 & [51] \\
\hline A356 & Varying & Varying & 8.2 & 5 & [53] \\
\hline AA6061 & 1500 & 50 & 6 & 2 & [55] \\
\hline Al-Si-9Mg & 560 & 355 & 6 & - & [56] \\
\hline
\end{tabular}

\subsection{Hardness}

Paider et al. [56] discovered that the number of grain boundaries had a direct relationship with the FSP number of passes. The hardness in the stir zone was found to increase as the number of passes increased. This phenomenon was due to the increase in the reduced grain size. A three-pass FSP was applied on the 7B04-O aluminium alloy to evaluate the changes in the mechanical properties in comparison to those of the single-pass FSP [57]. The results revealed an increase of about $40 \mathrm{HV}$ compared to the base material one. Moharrami et al. [58] discovered that when the AA6082 alloy was subjected to six-pass FSP, the hardness was improved from 178-270 HV. Similarly, the multi-pass FSP also increased the hardness of the A390 alloy when compared to that of the single-pass [59]. The hardness was found to increase with an increase in the number of FSP passes.

The impact of the multi-pass FSP on AA5083-H11 plate was investigated by Gandra et al. [60]. The bending and hardness tests were conducted to analyse the ductility of the multi-pass surface in 
comparison to that of the single-pass FSP. The results revealed that an improvement of 18 and 19\% for the mechanical resistance and toughness under bending was obtained. Whereas the hardness was found to have increased by $8.5 \%$ compared to that of the single-pass. Similar studies where the application of multi-pass FSP increased hardness were reported [61-66]. Surekha et al. [67] subjected the AA2219 alloy to multi-pass FSP and found that the hardness of the stir zone was lower compared to that of the base material. The study by Ghanbari et al. [68] also confirmed that when the AA2024 was subjected to multi-pass FSP the hardness of the stir zone decreased with an increase in the number of FSP passes. Various studies were found to have similar behaviour as far as hardness is concerned [69-73].

In as much as the multi-pass has been proven to enhance or decrease the hardness of a specific material, it can also not affect the stir zone hardness. Johannes et al. [40] upon studying the effect of multi-pass FSP on the AA7075 alloy with a $42 \%$ overlap between the passes, proved the hardness to be constant in all the passes. Similar findings were reported by Khorrami et al. [74]. Table 3 shows the sample of processing parameters concerning the impact the multi-pass FSP has on the hardness of the respective aluminium alloys.

Table 3. Multi-pass FSP processing parameters -hardness.

\begin{tabular}{|c|c|c|c|c|c|}
\hline \multirow{2}{*}{$\begin{array}{l}\text { Aluminium } \\
\text { alloy }\end{array}$} & \multicolumn{3}{|c|}{ Parameters } & \multirow{2}{*}{$\begin{array}{l}\text { No. of } \\
\text { passes }\end{array}$} & \multirow[t]{2}{*}{ Reference } \\
\hline & $\begin{array}{l}\text { Tool rotational } \\
\text { speed (rpm) }\end{array}$ & $\begin{array}{l}\text { Traverse speed } \\
(\mathrm{mm} / \mathrm{min})\end{array}$ & $\begin{array}{l}\text { Material } \\
\text { thickness (mm) }\end{array}$ & & \\
\hline AA7B04 & 400 & 200 & 2 & 3 & [57] \\
\hline A390 & 1200 & 20 & 2 & 3 & [59] \\
\hline AA5083-H111 & 1000 & 25 & 8 & 2 & [60] \\
\hline AA5083-H111 & 1000 & 120 & 6 & 2 & [61] \\
\hline AA2024 & 1000 & 80 & 3.5 & 3 & [62] \\
\hline AA2014 & 1100 & 30 & 4 & 3 & [64] \\
\hline AA2219-T87 & Varying & Varying & 5 & 3 & [67] \\
\hline AA7075 & 1000 & 200 & 3 & 4 & [69] \\
\hline AA6063 & 600 & 145 & 12 & 2 & [71] \\
\hline
\end{tabular}

\subsection{Corrosion}

Wang et al.[75] investigated the effect of multi-pass FSP on the corrosion property of AA6061T6. The FSP was performed under normal (air) and underwater conditions. The immersion test and electrochemical corrosion test were used to examine the corrosion behaviour. The results revealed a refined stir zone grain structure. The corrosion resistance of the FSPed stir zones for both conditions was better compared to that of the base material. The stir zone was reported to exhibit higher free corrosion potential, smaller corrosion current density and greater corrosion impedance than that of the base material. Better corrosion resistance was found on the stir zone of the normal FSP in comparison to that of the underwater FSP. Rao et al. [76] applied multi-pass FSP on the AL-30Si alloy intending to analyse the corrosion resistance of the friction stir processed alloy. The increase in the number of passes resulted in a decrease in the corrosion rate of the alloy. This behaviour was said to be due to the homogeneity of the microstructure, reduction in the grain size and silicon particle size.

The corrosion behaviour of the AA6061 alloy subjected to 0.5 to $1 \mathrm{~mm}$ overlap multi-pass FSP was investigated [77]. The electrochemical work station was used to study the corrosion behaviour of the top surface o the FSPed sample. The SEM analysis was performed on the corroded samples. It was reported that the application of multi-pass FSP resulted in greatly improved corrosion resistance compared to the single-pass one. The improvement was substantiated to be owed to the refined, homogeneous grain structure as well as the discontinuous precipitates. Similar studies where the application of multi-pass FSP resulted in improved corrosion resistance were reported [67, 78]. 
Esmaily et al. [79] evaluated the corrosion behaviour of the multi-pass FSPed AA6005-T6 alloy. The samples were contaminated with $\mathrm{NaCl}(70$ and $200 \mathrm{mu}$ g/cm2) and exposed to $400 \mathrm{ppm}$ carbon dioxide for a 200-3200 $\mathrm{h}$ time interval. The increase in the number of FSP passes resulted in a decrease in pitting corrosion in the stir zone. However, the heat-affected zone was reported to have an induced significant pitting corrosion attack which was associated with the reduction of the intermetallic particle size in the stir zone.

Yang et al. [80] conducted a study on the corrosion resistance of the multi-pass FSP of the AA2024-T3/Al2O3 metal matrix composites. The cyclic polarization, electrochemical impedance spectroscopy was used to study the effect of the passes of the composites with the $3.5 \mathrm{wt} \%$ of $\mathrm{NaCl}$. It was also reported that the 4 pass FSP of the AA2024-T3 alloy resulted in a decrease in corrosion resistance because of the improved surface condition and deteriorated interface inside the coatings. Nevertheless, the second pass was said to have the best corrosion performance. Satyanarayana and Kumar [81] also discovered that the processing conditions also play a critical role in the corrosion resistance of the multi-pass FSPed AA2014 alloy. The underwater condition resulted in higher corrosion resistance compared to normal conditions. The processing parameters used in this section are presented in Table 4.

Table 4. Multi-pass FSP processing parameters -corrosion.

\begin{tabular}{|c|c|c|c|c|c|}
\hline \multirow{2}{*}{$\begin{array}{l}\text { Aluminium } \\
\text { alloy }\end{array}$} & \multicolumn{3}{|c|}{ Parameters } & \multirow{2}{*}{$\begin{array}{l}\text { No. of } \\
\text { passes }\end{array}$} & \multirow[t]{2}{*}{ Reference } \\
\hline & $\begin{array}{l}\text { Tool rotational } \\
\text { speed (rpm) }\end{array}$ & $\begin{array}{c}\text { Traverse } \\
\text { speed }(\mathrm{mm} / \mathrm{min})\end{array}$ & $\begin{array}{c}\text { Material } \\
\text { thickness (mm) }\end{array}$ & & \\
\hline A356 & 350 & 16 & 12 & 3 & [76] \\
\hline AA6061-T6 & 800 & 40 & 6 & 5 & [77] \\
\hline AA5052 & 1000 & 14 & 6 & 4 & [78] \\
\hline AA6005-T6 & 1200 & 500 & 10 & 3 & [79] \\
\hline AA2024-T3 & 900 & 50 & 2.5 & 4 & [80] \\
\hline AA2014 & 900 & 50 & 2.5 & 4 & [81] \\
\hline
\end{tabular}

\section{Summary}

It is undeniable that FSP has an exceptional record in being an enhancement technique to soft alloys including aluminium. From the literature available on the multi-pass FSP, it has been observed that the majority of those works focused on the processing of plates. There is no searchable literature reporting on the multi-pass friction stir processing of welded joints. This then opens a gap to pursue the multi-pass friction stir processing of welded aluminium alloy joints including both similar and dissimilar. It is of uttermost importance to focus on the multi-pass FSP of dissimilar joints, due to most industries opting towards using dissimilar alloys in producing various components.

Author Contributions: Conceptualization, V.M.; methodology, S.M.; validation, S.M., O.M. and V.M.; formal analysis, S.M.; investigation, S.M.; resources, V.M.; data curation, S.M. and O.M.; writing-original draft preparation, O.M.; writing-review and editing, S.M.; visualization, O.M.; supervision, V.M.; project administration, V.M.; funding acquisition, V.M. All authors have read and agreed to the published version of the manuscript.

Funding: Please add: "This research received no external funding" or "This research was funded by the National Research Foundation (NRF) Thuthuka.

Acknowledgments: Special gratitude also goes to the Cape Peninsula University of Technology for unlimited access to the respective equipment needed for the study.

Conflicts of Interest: The authors declare no conflict of interest. The funders had no role in the design of the study; in the collection, analyses, or interpretation of data; in the writing of the manuscript, or in the decision to publish the results. 


\section{References}

1. Chung, D.D.L. Composite Materials Science and Applications, 2nd ed., Springer, New York, 2010

2. Liu, H.J.; Fujii, H.; Maeda, M.; Nogi, K. Mechanical properties of friction stir welded joints of $1050-\mathrm{H} 24$ aluminium alloy. Sci. Technol. Weld. Join., 2003, 8:6, 450-454, https://doi.org/10.1179/136217103225005598.

3. Ilangovan, M.; Rajendra Boopathy, S.; Balasubramanian, V. Microstructure and tensile properties of friction stir welded dissimilar AA6061-AA5086 aluminium alloy joints. Trans. Nonferrous Metals Society: China, 2015, 25:4, 1080-1090, https://doi.org/10.1016/S1003-6326(15)63701-3.

4. Ashby, M.F.; Zones, D.R.H. Engineering Materials, vol. 2, Butterworth-Heinemann, 2nd edition, 1998.

5. Sampath, P.; Parangodath, V.K.; Udupa, K.R.; Kuruveri, U.B. Fabrication of friction stir processed Al-Ni particulate composite and its impression creep behaviour. Journal of Composites, 2015, 428630, 1-9, https://doi.org/10.1155/2015/428630.

6. Cam, G.; Kocak, M.; Progress in joining of advanced materials. Int. Mater. Rev. 1998, 43, 1-44.

7. Nicholas, E.D. Developments in the friction stir welding of metals. In Proceedings of the 6th International Conference on Aluminium Alloys, Toyohashi, Japan, 5-10 July 1998; 139-151.

8. Gupta, M.K. Friction stir process: a green fabrication technique for surface composites - a review paper. SN Appl. Sci. 2020, 2, 532, https://doi.org/10.1007/s42452-020-2330-2.

9. Thomas, W.M.; Nicholas, E.D.; Needham, J.C.; Murch, M.G.; Smith, P.; Dawes, C.G. Friction Stir Butt Welding, G.B. Patent Application No. 9125978.8.

10. Sun, N. 2009. Friction stir processing of aluminium alloys. Master of Science Thesis. Lexington, Kentucky.

11. Mishra, R.S.; Ma, Z.Y.; Charit, I. Friction stir processing: a novel technique for fabrication of surface composite. Mater. Sci. Eng. A, 2003, 341, 307-310.

12. Li, K.; Liu, X.; Zhao, Y. Research status and prospect of friction stir processing technology. Coatings, 2019, 9, 129. https://doi.org/10.3390/coatings9020129

13. Ma, Z.Y. Friction stir processing technology: a review. Metall. Mater. Trans. A, 2008, 39, 642-658, https://doi.org/10.1007/s11661-007-9459-0.

14. Patel, V.V.; Badheka, V.; Kumar, A. Friction stir processing as a novel technique to achieve superplasticity in aluminum alloys: process variables, variants, and applications. Metall. Microstruct. Anal. 2016, 5, 278293, https://doi.org/10.1007/s13632-016-0285-x.

15. Santella, M.L.; Engstrom, T.; Storjohann, D.; Pan, T.Y. Effects of friction stir processing on mechanical properties of the cast aluminum alloys A319 and A356. Scripta Materialia, 2005, 53, 201-206, https://doi.org/10.1016/j.scriptamat.2005.03.040.

16. Mishra, R.S.; Ma, Z.Y. Friction stir welding and processing. Mater. Sci. Eng. R Rep. 2005, 50, 1-78, https://doi.org/10.1016/j.mser.2005.07.001.

17. Yadav, D.; Bauri, R. Effect of friction stir processing on microstructure and mechanical properties of aluminium. Mater. Sci. Eng. A, 2012, 539, 85-92, https://doi.org/10.1016/j.msea.2012.01.055.

18. Jana, S.; Mishra, R.S.; Baumannn, J.B.; Grant, G. Effect of stress ratio on the fatigue behavior of a friction stir processed cast Al-Si-Mg alloy. Scripta Materialia 2009, 61, 992-995, https://doi.org/10.1016/j.scriptamat.2009.08.011.

19. Sharma, S.R.; Ma, Z.Y.; Mishra, R.S. Effect of friction stir processing on fatigue behavior of A356 alloy. Scripta Materialia 2004, 51, 237-241, https://doi.org/10.1016/j.scriptamat.2004.04.014.

20. Su, J.-Q.; Nelson, T.W.; Sterling, C.J. Friction stir processing of large-area bulk UFG aluminum alloys. Scripta Materialia, 2005, 52(2), 135-140, https://doi.org/10.1016/j.scriptamat.2004.09.014.

21. Chen, Y.; Ding, H.; Li, J.; Cai, Z.; Zhao, J.; Yang, W. (2016). Influence of multi-pass friction stir processing on the microstructure and mechanical properties of Al-5083 alloy. Mater. Sci. Eng. A, 2016, 650, 281-289, https://doi.org/10.1016/j.msea.2015.10.057.

22. Brown, R.; Tang, W.; Reynolds, A.P. Multi-pass friction stir welding in alloy 7050-T7451: Effects on weld response variables and on weld properties. Mater. Sci. Eng. A, 2009, 513-514, 115-121, https://doi.org/10.1016/j.msea.2009.01.041.

23. El-Rayes, M.M.; EI-Danaf, E.A. The influence of multi-pass friction stir processing on the microstructural and mechanical properties of Aluminum Alloy 6082. J. Mater. Process. Technol. 2012, 212, 1157-1168. https://doi.org/10.1016/j.jmatprotec.2011.12.017. 
24. Johannes, L.B.; Charit, I.; Mishra, R.S.; Verma, R. 2007. Enhanced superplasticity through friction stir processing in continuous cast AA5083 aluminum. Mater. Sci. Eng., 2007, A 464, 351-357, https://doi.org/10.1016/j.msea.2007.02.012.

25. Aktarer, S.M.; Sekban, D.M.; Saray, O.; Kucukomeroglu, T.; Ma, Z.Y.; Purcek, G. Effect of two-pass friction stir processing on the microstructure and mechanical properties of as-cast binary Al-12Si alloy. Mater. Sci. Eng. A, 2015, 636, 311-319, https://doi.org/10.1016/j.msea.2015.03.111.

26. Nadammal, N.; Kailas, S.V.; Szpunar, J.; Suwas, S. Microstructure and texture evolution during single- and multiple-pass friction stir processing of heat-treatable aluminum alloy 2024. Metall. Mater. Trans. A, 2017, 48(9), 4247-4261, https://doi.org/10.1007/s11661-017-4184-9.

27. Akinlabi, E.; Oyindamola, K.; Olufayo, O.; Agarana, M. Effect of multi-pass friction stir processing on mechanical properties of AA6061-T6. IJMET, 2018, 9:6, 667-679.

28. Panigrahia, S.; Kumara, K.; Yuana, W. Transition of deformation behavior in an ultrafine grained magnesium alloy. Mater. Sci. Eng. A, 2012, 549, 123-127, https://doi.org/10.1016/j.msea.2012.04.017.

29. Yuan, W.; Panigrahi S.; Mishra, R. Influence of grain size and texture on Hall-Petch relationship for a magnesium alloy. Scripta Materialia, 2011, 65, 994-997, https://doi.org/10.1016/j.scriptamat.2011.08.028.

30. Singh, S.K.; Immanuel, R.J.; Babu, S.; Panigrahi, S.K.; Janaki Ram, G.D. Influence of multi-pass friction stir processing on wear behaviour and machinability of an Al-Si hypoeutectic A356 alloy. J. Mater. Proc. Technol., 2016, 236, 252-262, https://doi.org/10.1016/j.jmatprotec.2016.05.019.

31. [31] Paidar M, Ojo O.O, Ezatpour H.R, Heidarzadeh A. Influence of multi-pass FSP on the microstructure, mechanical properties and tribological characterization of $\mathrm{Al} / \mathrm{B} 4 \mathrm{C}$ composite fabricated by accumulative roll bonding (ARB), Surf. Coating

32. Soustani, M.F.; Taghiabadi, R.; Jafarzadegan, M.; Vasheghani Farahani, M. Effect of multi-pass friction stir processing on microstructure and mechanical properties of cast Al-7Fe-5Ni alloy. Mater. Res. Express, 2019, 6:10, 106571, https://doi.org/10.1088/2053-1591/ab3829.

33. Nadammal, N.; Kailas, S.V.; Szpunar, J.; Suwas, S. Development of microstructure and texture during single and multiple pass friction stir processing of a strain hardenable aluminium alloy. Mater. Charact., 2018, 140, 134-146, https://doi.org/10.1016/j.matchar.2018.03.044.

34. Tutinchilar, S.; Besharati, G.M.K.; Haghpanahi, M.; Asadi, P. Eutectic Al-Si piston alloy surface transformed to modified hypereutectic alloy via FSP. Mater. Sci. Eng. A, 2012, 534, 557-567, https://doi.org/10.1016/j.msea.2011.12.008.

35. Yang, Y.; Hua, P.; Li, X.; Chen, K.; Zhou, W. Effect of multipass on microstructure and impact toughness of as-cast Al-20Si alloy via friction stir processing. Phys. Met. Metallogr., 2019, 120:11, 1126-1132, https://doi.org/10.1134/S0031918X1911005X.

36. Prasad, R.; Tewari, S.P.; Singh, J.K. Effect of multi-pass friction stir processing on microstructural, mechanical and tribological behaviour of as-cast Al-Zn-Mg-Cu alloy. Mater. Res. Express, 2019, 6:9, 096579, https://doi.org/10.1088/2053-1591/ab308c.

37. Hussain, G.; Ranjbar, M.; Hassanzadeh, S. Trade-off among mechanical properties and energy consumption in multi-pass friction stir processing of Al7075 alloy employing neural network-based genetic optimization. Proceedings of the Institution of Mechanical Engineers, Part B: J. Eng. Manuf., 2016, 23:1, 129139, https://doi.org/10.1177/0954405415569817.

38. Gan, W.Y.; Zheng, Z.; Zhang, H.; Tao, P. Evolution of microstructure and hardness of aluminum after friction stir processing. Trans. Nonferrous Met. Soc. China, 2014, 24:4, 975-981, https://doi.org/10.1016/S10036326(14)63151-4.

39. John Baruch, L.; Raju, R.; Balasubramanian, V.; Rao, A.G. I. Dinaharan. Influence of Multi-pass Friction Stir Processing on Microstructure and Mechanical Properties of Die Cast Al-7Si-3Cu Aluminum Alloy. Acta Metall. Sin. (Engl. Lett.), 2016, 29:5, 431-440, https://doi.org/10.1007/s40195-016-0405-2.

40. Johannes, L.; Mishra, R. Multiple passes of friction stir processing for the creation of superplastic 7075 aluminum. Mater. Sci. Eng.: A, 2007, 464:1-2, 55-260, https://doi.org/10.1016/j.msea.2007.01.141.

41. Ma, Z.; Mishra, R.S.; Liu, F. Superplastic behavior of micro-regions in two-pass friction stir processed 7075Al alloy. Mater. Sci. Eng.: A, 2009, 505, 70-78, https://doi.org/10.1016/j.msea.2008.11.016.

42. Meenia, S.; Khan, M.D.F.; Babu, S.; Immanuel, R. J.; Panigrahi, S.K.; Janaki Ram, G.D. Particle refinement and fine-grain formation leading to enhanced mechanical behaviour in a hypo-eutectic Al-Si alloy subjected to multi-pass friction stir processing. Mater. Charact., 2016, 113, 134-143, https://doi.org/10.1016/j.matchar.2016.01.011. 
43. Wais, A.M.H.; Salman, J.M.; Roubaiy, A.O.A. Int. J. Sci. Res., 2013, 2, 2319-7064.

44. Rao, A.G.; Rao, B.R.K.; Deshmukh, V.P.; Shah, A.K.; Kashyap, B.P. Microstructural refinement of a cast hypereutectic Al-30Si alloy by friction stir processing. Mater. Lett., 2009, 63, 2628-2630, https://doi.org/10.1016/j.matlet.2009.09.022.

45. Pradeep, S.; Sharma, S.K.; Pancholi, V. Microstructural and mechanical characterization of friction stir processed 5086 aluminum alloy. Mater. Sci. Forum, 2012, 710, 253-257, https://doi.org/10.4028/www.scientific.net/msf.710.253.

46. Nakata, K.; Kim, Y.G.; Fujii, H.; Tsumura, T.; Komzaki, T. Improvement of mechanical properties of aluminum die casting alloy by multi-pass friction stir processing. Mater. Sci. Eng. A, 2006, 437, 274-280, https://doi.org/10.1016/j.msea.2006.07.150.

47. Ramesh, K.N.; Pradeep, S.; Pancholi, V. Multipass friction-stir processing and its effect on mechanical properties of aluminum alloy 5086. Metall. Mater. Trans A, 2012, 43:11, 4311-4319. https://doi.org/10.1007/s11661-012-1232-3.

48. Yang, R.; Zhang, Z.; Zhao, Y.; Chen, G.; Guo, Y.; Liu, M.; Zhang, J. Effect of multi-pass friction stir processing on microstructure and mechanical properties of Al3Ti/A356 composites. Mater. Charact., 2015, 106, 62-69, http://dx.doi.org/10.1016/j.matchar.2015.05.019.

49. Guru, P.R.; Khan MD, F.; Panigrahi, S.K.; Ram, G.D.J. Enhancing strength, ductility and machinability of aAl-Si cast alloy by friction stir processing. J. Manuf. Process. 2015, 18, 67-74, http://dx.doi.org/10.1016/j.jmapro.2015.01.005.

50. Cui, G.R.; Ni, D.R.; Ma, Z.Y.; Li, S.X. Effects of Friction stir processing parameters and in situ passes on microstructure and tensile properties of Al-Si-Mg casting. Metall. Mater. Trans. A, 2014, 45, 5318-5331, https://doi.org/10.1007/s11661-014-2494-8.

51. Vyas, H.; Mehta, K.P. Effect of multi pass friction stir processing on surface modification and properties of aluminum alloy 6061. Key Engineering Materials 2019, 813, 404-410, https://doi.org/10.4028/www.scientific.net/kem.813.404.

52. Węglowski, M.K.; Kopyściański, M.; Dymek, S. Friction stir processing multi-run modification of cast aluminum alloy. Key Eng. Mater., 2014, 611-612, 1595-1600, https://doi.org/10.4028/www.scientific.net/KEM.611-612.1595.

53. Lezaack, M.B.; Simar, A.; Zhao, L. Ductilization By Multi-Pass Friction Stir Processing Of Thick 7475 Aluminium Alloy. Light MAT 2019, Manchester, UK, 05 November 2019 - 07 November 2019, http://hdl.handle.net/2078.1/221887.

54. Saini, N.; Pandey, C.; Dwivedi, D.K. Ductilizing of cast hypereutectic Al-17\%Si alloy by friction stir processing. Proceedings of the Institution of Mechanical Engineers, Part E: J. Process Mech. Eng., 2018, 232:6, 696-701, https://doi.org/10.1177/0954408917737735.

55. Liu, Z.Y.; Xiao, B.L.; Wang, W.G.; Ma, Z.Y. Analysis of carbon nanotube shortening and composite strengthening in carbon nanotube/aluminum composites fabricated by multi-pass friction stir processing. Carbon 2014, 69, 264-274, https://doi.org/10.1016/j.carbon.2013.12.025.

56. Paidar, M.; Asgari, A.; Ojo O.O.; Saberi, A. Mechanical properties and wear behavior of AA5182/WC nanocomposite fabricated by friction stir welding at different tool traverse speeds. JMEPEG, 2018, 27, 1714724, https://doi.org/10.1007/s11665-018-3297-7.

57. Chen, Y.; Ding, H.; Malopheyev, S.; Kaibyshev, R.; Cai, Z.; Yang, W. Influence of multi-pass friction stir processing on microstructure and mechanical properties of 7B04-O Al alloy. Trans. Nonfer. Met. Soc. China, 2017, 27:4, 789-796, https://doi.org/10.1016/s1003-6326(17)60090-6.

58. Moharrami, A.; Razaghian, A.; Paidar, M.; Šlapáková, M.; Ojo, O. O.; Taghiabadi, R. Enhancing the mechanical and tribological properties of $\mathrm{Mg} 2 \mathrm{Si}$-rich aluminum alloys by multi-pass friction stir processing. Mater. Chem. Phys., 2020, 250, 123066, https://doi.org/10.1016/j.matchemphys.2020.123066.

59. Mahmoud, T.S. Surface modification of A390 hypereutectic Al-Si cast alloys using friction stir processing. Surface E Coatings Technol., 2013, 228, 209-220, https://doi.org/10.1016/j.surfcoat.2013.04.031.

60. Gandra, J.; Miranda, R.M.; Vilaça, P. Effect of overlapping direction in multipass friction stir processing. Mater. Sci. Eng.: A, 2011, 528:16-17, 5592-5599, https://doi.org/10.1016/j.msea.2011.03.105.

61. Papantoniou, I.G.; Markopoulos, A.P.; Manolakos, D.E. New approach in surface modification and surface hardening of aluminum alloys using friction stir process: Cu-reinforced AA5083. Mater., 2020, 13:6, 1278, https://doi.org/10.3390/ma13061278. 
62. Moustafa, E. Effect of Multi-Pass Friction Stir Processing on Mechanical Properties for AA2024/A12O3 Nanocomposites. Mater., 2017,10:9, 1053, https://doi.org/10.3390/ma10091053.

63. Gangil, N.; Maheshwari, S.; Siddiquee, A.N. Multipass FSP on AA6063-T6 Al: Strategy to fabricate surface composites, Mater. Manuf. Processes, 2018, 33:7, 805-811, https://doi.org/10.1080/10426914.2017.1415448.

64. Satyanarayana, M.V.N.V.; Kumar, A. Effect of heat treatment on AA2014 alloy processed through multipass friction stir processing. J. Phys.: Conference Series, 2019, 1240, 012077. https://doi.org/10.1088/17426596/1240/1/012077.

65. Sinhmar, S.; Dwivedi, D.K.; Pancholi, V. Friction stir processing of the AA7039 alloy. International Conference on Production and Mechanical Engineering (ICPME'2014), December 30-31, 2014 Bangkok, Thailand, 75-78, http://dx.doi.org/10.15242/IAE.IAE1214206.

66. García-Vázquez, F.; Vargas-Arista, B.; Muñiz, R.; Ortiz, J.C.; García, H.H.; Guru, J.A. the role of friction stir processing (FSP) parameters on TiC reinforced surface Al7075-T651 aluminum alloy. Soldagem E Inspeção, 2016, 21:4, 508-516, http://dx.doi.org/10.1590/0104-9224/SI2104.10.

67. Surekha, K.; Murty, B.; Raok, K.P. Microstructural characterization and corrosion behavior of multipass friction stir processed AA2219 aluminum alloy. Surf. Coat. Technol., 2008, 202, 4057-4068, https://doi.org/10.1016/j.surfcoat.2008.02.001.

68. Ghanbari, D.; Asgarani, M.K.; Amini, K.; Gharavi, F. Influence of heat treatment on mechanical properties and microstructure of the AA2024/SiC composite produced by multi-pass friction stir processing. Measurement, 2017, 104, 151-158, https://doi.org/10.1016/j.measurement.2017.03.024.

69. Matsuda, Y.; Itoh, G.; Motohashi, Y. Microstructure control and mechanical properties of 7075 aluminum alloy by means of multi-pass friction stir processing. Advanced Materials Research, 2012, 409, 281-286. https://doi.org/10.4028/www.scientific.net/amr.409.281

70. Krishna, V.V.M.; Satyanarayana, K. Microstructure and mechanical properties of multipass friction stir processed aluminum silicon carbide metal matrix, Int. J. Sci. Eng. Technol., 2015, 4:2, 88-90.

71. Al-Fadhalah, K.J.; Almazrouee, A.I. Microstructure and mechanical properties of multi-pass friction stir processed aluminum alloy 6063. Mater. Des., 2014, 53, 550-560, https://doi.org/10.1016/j.matdes.2013.07.062.

72. Mirjavadi, S.S.; Alipour, M.; Hamouda, A.M.S.; Matin, A.; Kord, S.; Afshari, B.M.; Koppad, P.G. Effect of multi-pass friction stir processing on the microstructure, mechanical and wear properties of AA5083/ZrO2 nanocomposites. J. Alloys Compd., 2017, 726, 1262-1273, https://doi.org/10.1016/j.jallcom.2017.08.084.

73. Rastabi, S.A.; Mosallaee, M. Effect of multi-pass friction stir processing and Mg addition on microstructure and tensile properties of Al-1050 alloy. Int. J. Miner. Metall. Mater., 2020, 1-24, https://doi.org/10.1007/s12613-020-2074-4.

74. Khorrami, M.S.; Kazeminezhad, M.N.; Kokabi, A.H. The effect of SiC nanoparticles on the friction stir processing of severely. Mater. Sci. Eng. A, 2014, 602, 110-118, https://doi.org/10.1016/j.msea.2014.02.067.

75. Wang, M.; Liu, Q.; Zhang, Y.; Zhang, N.; Liu, M.Corrosion Property of Al-Alloy 6061-T6 processed by multi-pass friction stir processing. Chinese J. Mater Res., 2015, 29:8 589-594 https://doi.org/10.11901/1005.3093.2014.669.

76. Rao, A.G.; Katkar, V.A.; Gunasekaran, G.; Deshmukh, V.P.; N. Prabhu, Kashyap, B.P. Effect of multipass friction stir processing on corrosion resistance of hypereutectic Al-30Si alloy. Corr. Sci., 2014, 83:198-208, https://doi.org/10.1016/j.corsci.2014.02.013.

77. Satyanarayana, M.V.N.V.; Adepu, K.; Chauhan, K. Effect of overlapping friction stir processing on microstructure, mechanical properties and corrosion behavior of AA6061 alloy. Met. Mater. Int., 2020, https://doi.org/10.1007/s12540-020-00757-y.

78. Mansour, R.; Hamed, J. The influence of multipass friction stir processing on the corrosion behavior and mechanical properties of zircon-reinforced Al metal matrix composites. Mater. Sci. Eng.: A, 2016, 671, 214220, https://doi.org/10.1016/j.msea.2016.05.056.

79. Esmaily, M.; Mortazavi, N.; Osikowicz, W.; Hindsefelt, H.; Svensson, J. E.; Halvarsson, M.; Johansson, L. G. Influence of Multi-Pass Friction Stir Processing on the Corrosion Behavior of an Al-Mg-Si Alloy. J. Electrochemical Society, 2016, 163:3, C124-C130. https://doi.org/10.1149/2.1091603jes.

80. Yang, K.; Li, W.; Xu, Y.; Yang, X. Using friction stir processing to augment corrosion resistance of cold sprayed AA2024/Al2O3 composite coatings, J. Alloys Comp., 2019, 774, 1223-1232, https://doi.org/10.1016/j.jallcom.2018.09.386. 
81. Satyanarayana, M.; Kumar, A. Influence of cooling media in achieving grain refinement of AA2014 alloy using friction stir processing. Proceedings of the Institution of Mechanical Engineers, Part C: J. Mech. Eng. Sci. 2020, https://doi.org/10.1177/0954406220922858. 